\title{
FREEDOM OF SPEECH AND PRESS UNDER THE FIRST AMENDMENT: A RESUMÉ
}

\author{
EDWard S. Corwin \\ Princeton University
}

\begin{abstract}
"Congress shall make no law respecting an establishment of religion, or prohibiting the free exercise thereof; or abridging the freedom of speech or of the press; or the right of the people peaceably to assemble, and to petition the Government for a redress of grievances."'
\end{abstract}

The opponents of the Sedition Act of 1798 denied that the National Government had the right to enact any law whatever limiting freedom of the press. The critics of the Espionage $\mathrm{Act}^{2}$ do not in theory go so far-though actually they arrive at much the same result as did their predecessors. In brief their view of the matter may be stated thus: It was the purpose of the First Amendment of the Constitution to relieve the press in the United States of the restraints imposed by the common law doctrine of seditious libel, which condemned as criminal all publications having a tendency to bring Church or State, or the officers of the Government, or the administration of the law into contempt. It follows, therefore, that the legal condemnation of a writing because of the bad "intent" of the author or publisher thereof would also be contrary to the First Amendment, since this intent is ordinarily determined simply from the tendency of the writing. In fact, it is urged, there can be, under the Constitution, no such thing as seditious libel, however determined, but only the power to punish incitements to crime, when there is imminent danger that the incitement will prove successful; and if this doctrine is not embodied in the First Amendment, at least it is implied in our theory of government, which makes government the property of the people and not vice versa. ${ }^{3}$

This part of the argument is not impressive. It may very well be that just because the people feel the government to be theirs, they also feel that they may concede it power to protect itself and other social interests without too great danger to liberty. The question is, who are the people? The real basis of the interpretation of the First Amendment just given is the belief that the people are a moral unit, that the social contract still holds among all men, that there are no irreconcilables in our midst-and this belief may be questionable.

The main purpose of this article, however, is to examine the historical foundations of this interpretation of the First Amendment.

\footnotetext{
${ }^{1}$ Federal Constitution, Ist Amendment.

"For a detailed discussion of the Espionage Act and its amendments and of the cases arising under it, see Carroll, Freedom of Speech and of the Press in War Time: The Espionage Act (1919) I7 Mich. L. Rev. 621. See also Hart, Power of Government over Speech and Press (1920) 29 Yale Law Journaz, 4 ro.

${ }^{3}$ This, in general, seems to be the position taken by Zechariah Chafee, Jr., in his article, Freedom of Speech in War Time (1919) 32 HARv. L. REv. 932.
} 
This Amendment was written into the Constitution by students of Blackstone, in the pages of whose Commentaries the notion of the freedom of the press, from being a literary and political watchword, is first raised to the position of an accepted legal concept. But Blackstone's notion of freedom of the press, while it records the final result of an important historical struggle, is a somewhat modest one. Briefly, Blackstone defined freedom of the press as on the one hand freedom from restraint previous to publication, and on the other hand, subjection to the law for abuse of this freedom. Of course, the law which he has in mind is the common law of his day and includes, therefore, the common law of seditious libel. ${ }^{3 a}$

It is urged against Blackstone's right to be regarded as an expositor of the First Amendment, that he was a Tory and defended Parliament's right to tax the American Colonies, that he wrote before the enactment of Fox's Libel Act, and that his view overlooks, therefore, the grievance felt in England itself on account of certain trials for sedition which took place there in the course of the eighteenth century. ${ }^{*}$ These objections to a great extent answer one another. For if Blackstone was a Tory, Fox at least was a Whig, who resisted vehemently Parliament's right to tax America; and yet Fox felt it sufficient in order to meet English public sentiment on the subject of seditious libel, not to alter the substance of the common law, but merely the procedure by which it had come to be enforced, which had been to reserve the question of the tendency of the writing to the court, and so to leave to the jury the right only of passing upon the fact of publication and what was called "the truth of the innuendoes," that is to say, their meaning. The Libel Act of 1792 , however, by authorizing the jury to bring in a general verdict of "guilty" or "not guilty" in prosecutions for seditious libel, as for other crimes, virtually transferred the question of tendency also to the jury. This act, it should be noted, came after both the First Amendment and the Commentaries.

But the real question, of course, is not as to Blackstone's authority in relation to the First Amendment, but that of the common law. The First Amendment was preceded by provisions of a more sweeping character on the same subject in several of the early state constitutions. The "liberty of the press" is "inviolate," it is "not to be restrained," it is "to be inviolably preserved." Yet in exactly contemporaneous documents in neighboring states, the "responsibility" of those who enjoy this liberty for its "abuse" is pronounced and the occurrence of trials for "libel both criminal and civil" is prevised. It seems, indeed, very improbable that there was any idea in the minds of those who framed these provisions that they were repealing the ordinary standards of the common law; and as a matter of fact, prosecutions for seditious libel occurred even in the Igth century in

${ }^{3}$ See 4 Blackstone, Commentaries (Cooley's ed. I87r) I5I.

- See Chafee, op. cit. 938-939. 
States whose constitutions asserted "liberty of the press" in the broadest terms. ${ }^{5}$ 'ibery of the gre

But perhaps it will be rejoined that the fate of the Sedition Act at any rate proves that the First Amendment was regarded as having swept away the common law of seditious libel. ${ }^{8}$ In the words of Justice Holmes, in his dissent in the recent case of Abrams $v$. United States," "I had conceived that the United States through many years had shown its repentance for the Sedition Act of July I4, I798, by repaying fines that it had imposed." To begin with, this argument cannot refer to the first section of the Sedition Act, which penalized conspiracy to oppose the measures of the government and "counselling" or "advising" riot or insurrection. Even opponents of the act-though inconsistently with their main argument-refrained from demanding its repeal, and its provisions still remain in substance on the statute book, nearly one hundred and twenty years after the demise of the act.

The reference is, therefore, to the second section of the act, which provided that if any person should write, print, or publish any "false, scandalous, and malicious writing" against the Government of the United States, or either House of Congress, or the President, "with intent to defame" the same "or to bring them into contempt .. . or to stir up sedition within the United States," such persons should be liable to the penalties of the act. It is true, as Justice Holmes points out, that the United States subsequently remitted fines paid under this section; but why? On account of the definition which it gave to "freedom of the press"? To some extent perhaps, but principally because the act was deemed to represent an intrusion of the National Government into a field entirely closed to it and so reserved exclusively to the States. The other phase of the question was sometimes touched upon tentatively, but it involved too many pitfalls to be entered upon with assurance. Thus Nicholas of Virginia, who made the best argument delivered in Congress against the act, was forced to defend an act passed by Virginia herself during the Revolution, the opening section of which penalized "any word, open deed. or act" defending the jurisdiction of the British King or Parliament in Virginia. Asked how he reconciled such a measure with "liberty of the press," he answered:

"This section passed at the beginning of the most awful contest in which ever man was engaged . . . was to establish what? Not

\footnotetext{
${ }^{5}$ See Respublica v. Dennie ( 1805, Pa. N. P.) 4 Yeates, 267; see People v. Croszell (I804, N. Y. Sup. Ct.) 3 Johns. Cas. 337, discussed infra note I2.

- For a thorough and accurate discussion of the Sedition Act and the contemporary debate over it, see Carroll, Freedom of Speech and of the Press in the Federalist Period (1920) I8 Mich. L. Rev. 6r5.

' (IgIg) 250 U. S. 616, 40 Sup. Ct. 17. For comment on this case see Comments (Ig20) 29 Yale Law Journal, 337; Wigmore (1920) I4 IlL L. Rev. 539; Chafee (1920) 33 HARv. L. Rev. 747; D. K., id., 442; and a note (1920) 14 ILL. L. REv. 6aI.
} 
the inviolability of the Governor of the State, nor the majority of either House of the Legislature, but to punish men who should promote resistance to the right of the people to govern themselves, to the principle of the Constitution, to the Republican principle."s

Here, however, is the whole doctrine of "tendency" which underlies the common law of seditious libel, though the benefit of it is denied to persons. And of like import is the letter in which Jefferson, while the Sedition Act was still fresh in the minds of everybody, gave the signal for the impeachment of Justice Samuel Chase on account of the latter's "seditious attack" before-a grand jury at Baltimore "on the principles of our Government."

In the long run the protest against the Sedition Act accomplished two results: It laid to rest the idea of a national common law of seditious libel of which the act was merely declaratory; while within the States it rendered prosecution for political libels less and less, frequent until they ceased altogether, leaving officials dependent for their protection on the ordinary law of slander and libel. On the other hand, the opponents of the act were forced to make two important concessions, at least inferentially: First, that the National Government could regulate freedom of speech and of the press to the extent of forbidding the counselling of disorder and breach of the law; and secondly, that the State Constitutions had left the common law of seditious libel operative so far as was necessary to protect the fundamental principles of government in the United States. For the rest, the Sedition Act itself is notable as an effort to mitigate the rigors of the common law which spread its influence to the States and so became the starting point of a new formulation of "liberty of the press."

The second section of the Sedition Act, quoted above, marked two departures from the common law: The "scandalous and malicious" publications which it banned must also be "false," and further they must be uttered "with the intent" to bring about the results discountenanced by the act. The third section of the act took a farther step and provided that defendants under it should be permitted "to give in evidence, in their defense, the truth of the matter" charged to be libellous, and that the jury should have the right "to determine the law and the fact, under the direction of the court, as in other cases,"-a development which had indeed been foreshadowed by a decision of the Supreme Court in $1794^{10}$ The test of intent which was thus brought into the law of libel for the first time was a reëcho on this side the water of some of Erskine's famous pleas; the test of truth harks back, it may be surmised, to the famous Zenger Case,

${ }^{3}$ Annals (5th Cong.) col. $3005 \mathrm{ff}$. See also ibid. col. 2149 ff.

- See also Jefferson's letter to Mrs. Adams, September Ir, I804, 4 Writings of Thomas Jefferson (Washington ed.) 560.

${ }^{10}$ Brailsford v. Georgia (1794, U. S.) 3 Dall. I.

"12 (1735, N. Y.) I7 How. St. Tr. 675. 
which, though it had no value as a precedent, had left behind a widespread though badly confused tradition as to its import.

The later importance of the Sedition Act becomes evident as we turn for a moment to the case of State v. Croswell which came before the New York Supreme Court in I804. ${ }^{12}$ Croswell had been convicted of having published "a scandalous, malicious, and seditious libel" traducing Thomas Jefferson, President of the United States, and intending to bring him "into the great contempt" of the people of the United States and of the State of New York. At the close of the trial the Chief Justice had charged the jury that it was not part of their province to decide on the intent of the defendant "or whether the publication in question was true or false or malicious," but only "whether the defendant was the publisher of the piece charged in the indictment" and "as to the truth of the innuendoes." On appeal Alexander Hamilton, for "Croswell, attacked this ruling on the ground that the Sedition Act of 1798 had declared the common law for the United States. He then laid down a definition of liberty of the press which has been since repeated hundreds of times.

"The liberty of the press consists in the right to publish with impunity, truth, with good motives, for justifiable ends, though reflecting on government, magistracy, or individuals."

Hamilton's argument was accepted by Kent, who furthermore pointed out the place that the defense of truth ought to have in the entire defense, as follows:

"As a libel is a defamatory publication, made with a malicious intent, the truth or falsehood of the charge may, in many cases, be a very material and pertinent consideration. There can be no doubt that it is competent for the defendant to rebut the presumption of malice drawn from the fact of publication; and it is consonant to the general theory of evidence and the dictates of justice, that the defendant should be allowed to avail himself of every fact and circumstance that may serve to repel that presumption. And what can be a more important circumstance than the truth of the charge to determine the goodness of the motive in making it?"

Hamilton's view, supplemented by Kent's, did not, it is true, prevail with the courl, which rejected the contention that the Sedition Act established the common law for New York, and grounded their decision on Lord Mansfield's exposition of the common law in the Dean of St. Asaph's Case. ${ }^{13}$ But Hamilton's triumph was not long postponed. The same year a bill was introduced into the State legislature which embodied his definition of freedom of the press, linked up with the provisions of Fox's Libel Act, and twelve months later this bill was enacted into law by the unanimous vote of both houses. A few years later the same formula was iniroduced into the New York Constitution and to-day it finds place in nearly a third of our state constitutions.

\footnotetext{
${ }^{12}$ Supra note 5 , at p. 4 II. $\quad{ }^{13}$ (1784, K. B.) 4 Dolig. 73.
} 
Our modern liberals, however, object to this most widely prevalent definition of liberty of the press on the ground, as we have seen, that to the extent that the intent of the writer is judged from the tendency of his writing, the test of intent leaves the common law of seditious libel in effect. It is therefore argued that in order to render congressional legislation invoking the test of intent constitutional-since the First Amendment cannot be deemed to have presupposed the common law of seditious libel as definitive of freedom of the pressthis test must be given redefinition. Such, at least, I take it, is the purport of Justice Holmes's dissent in the recent Abrams case. ${ }^{14}$

The facts of this case, which already promises to become a notable one, were as follows: Abrams and others had printed and distributed circulars denouncing "the hypocrisy of the United States and her allies" and summoning the "workers" to "a general strike."

"Workers in the ammunition factories you are producing bullets, bayonets, cannon, to murder not only the Germans, but also your dearest, best, who are in Russia and are fighting for freedom. . . . Workers, up to fight."

On the strength of this and similar passages the defendants were convicted under the Espionage Act, one of the counts being that they had urged a curtailment of products essential to the prosecution of the war, "with intent by such curtailment to cripple or injure the United States in the prosecution of the war." From this verdict they appealed to the Supreme Court on the ground that there was no substantial evidence in the record to support it.

In the portion of his dissent above referred to, Justice Holmes admits that the defendants had urged a curtailment in the production of things necessary for the prosecution of the war, but he denies that there was evidence to show that this was done with the intent penalized by the act.

"I am aware that the word 'intent' as vaguely used in ordinary legal discussion means no more than the knowledge at the time of the act that the consequences said to be intended will ensue. . . But when words are used exactly, a deed is not done with intent to produce a consequence unless that consequence is the aim of the deed. . .

It seems to me that this statute must be taken to use its words in a strict and accurate sense. They would be absurd in any other. A patriot might think that we were wasting money on aeroplanes . . and might advocate curtailment with success; yet, even if it turned out that the curtailment hindered ... the United States in the prosecution of the war, no one could hold that conduct a crime."

The clear implication of Justice Holmes's language is that the legal test of intent establishes a conclusive presumption, and that is not so. I have not the charge in the Abrams case before me, but another charge under the same act reads thus: 
"If you find beyond a reasonable doubt that the defendant did in fact utter the words imputed to him in the indictment or words in substance and effect like them, in determining what their purpose and intent was in so doing, you will have a right to consider what would be the natural, usual, and necessary consequences of uttering such words at the time and place and in the presence and hearing of the people referred to in the indictment."15

Then the charge proceeds a little further on as, follows:

"There is no presumption which is conclusive, either in law or in fact, that he actually intended what may appear to you to be the natural, usual, and necessary consequences of uttering such words, and you will consider this matter in connection with all the other evidence in the case for the purpose of determining what was in fact the defendant's actual purpose and intent."16

There would be, I suspect, little difficulty in clearing Justice Holmes's advocate of curtailment in aeroplane production under such a charge, especially if that person were discreet enough to refrain from applying the term "murder" to the war which he was ostensibly promoting. But even as to Abrams and his associates, it cannot be admitted that the application of the legal doctrine of intent to their case did injustice. As Justice Clarke points out in his opinion for the Court, these men were entirely willing to cripple the prosecution of the war with Germany if only by so doing they might also cripple action against Russia. In law, as in ethics and in common sense, men must be held to intend, if not the usual consequences of their acts, certainly the necessary means to their objectives.

The issue raised by Justice Holmes is at basis the historical issue. $\mathrm{He}$ is at one with those who urge that Congress must stop short, in its regulation of speech and the press, with punishing words which "directly incite to acts in violation of law" and which "bring the speaker's [or writer's] unlawful intention reasonably near to success."17 His own words are:

"The United States constitutionally may punish speech that produces or is intended to produce" (the sense in which the word "intended" is used in this passage is left uncertain) "a clear and imminent danger that it will bring about forthwith certain substantive evils that the United States constitutionally may seek to prevent."18

There is no doubt that the United States has this power-that was

\footnotetext{
${ }^{15}$ Italics mine.

10 Interpretation of War Statutes (Igr8) Bull. I9r. See also to the same effect Bulls. $4,49,52,79,83,112,116,123,131,133,142,143,148,149$, I56, etc. $C f$. also Kent's language quoted supra.

${ }^{17}$ Chafee, op. cit. note $3 x$ at pp. 947-948.

${ }^{18}$ This seems to imply that the court may hold as a matter of law that the probability of harm resulting from an utterance is so remote that a conviction under the law for such utterance is unwarrantable. See also his words in Frohwerk v. United States (I9I9) 249 U. S. 204, 39 Sup. Ct. 249.
} 
admitted in effect even by opponents of the Alien and Sedition Acts. But is this the limit of its power? The foregoing historical sketch does not support an affirmative answer to this question, nor do general principles. The elbow-room accorded Congress by the "necessary and proper" clause is admittedly broad, and it is a sound maxim of constitutional interpretation that the Constitution does not grant power in one place to withdraw it in another..$^{19}$ The majority in the Abrams case stand on secure ground. ${ }^{20}$

There is another aspect to this subject. For the most part those who are endeavoring to-day to elaborate constitutional restrictions upon Congress's power over the press have shown themselves in the past distinctly opposed to the curtailment of legislative discretion by definite, unbending constitutional limitations. Personally, I am disposed to agree with their earlier rather than their later position. Amid the uncomplicated conditions of frontier life it was entirely feasible to assure each individual a certain quantum of "inalienable rights," but to-day the pursuit of happiness has become a joint-stock enterprise in which the welfare of all is embarked. In this situation it is much more to the point to insist upon the responsibility of legislators than their lack of power. Besides, is there anyone who seriously supposes that fair discussion of men and measures looking to the realization of public ends by lawful means is, or is likely to be, in any peril in this country from government? The real peril is quite a different one-but that is another story.

To sum up, the following propositions seem to be established with respect to constitutional freedom of speech and press: first, Congress is not limited to forbidding words which are of a nature "to create a clear and present danger" to national interests, but it may forbid words which are intended to endanger those interests if in the exercise of a fair legislative discretion it finds it "necessary and proper" to do so ;21 second, the intent of the accused in uttering the alleged forbidden words may be presumed from the reasonable consequences of such words, though the presumption is a rebuttable one; third, the court will not scrutinize on appeal the findings of juries in this class of cases more strictly than in other penal cases. In short, the cause of freedom of speech and press is largely in the custody of legislative majorities and of juries, which, so far as there is evidence to show, is just where the framers of the Constitution intended it to be.

${ }^{10}$ See Billings v. United States (1914) 232 U. S. 26I, 34 Sup. Ct. 42I; Brushaber v. Union Pacific R. Co. (IgI5) 240 U. S. x, 36 Sup. Ct. 236.

- 20 They continue, moreover, to hold their ground in the subsequent cases of Pierce v. United States (I920, U. S.) 40 Sup. Ct. 205, and Schaefer v. United States (1920, U. S.) 40 Sup. Ct. 259.

IT The party platforms and recent utterances of Attorney General Palmer make it clear that the good sense of the country is coming to the conclusion that to ban utterances advocating or threatening violence is all that is required at present. 